\title{
EKSISTENSIALISME DAN ABSURDISME DALAM DRAMA KARYA PUTU WIJAYA
}

\author{
Engkin Suwandana \\ Universitas Islam Majapahit \\ E-mail: engkin.suwandana@mail.unesa.ac.id
}

\begin{abstract}
Abstrak
Penelitian ini bertujuan (1) mendeskripsikan eksistensialisme dalam drama Aduh, Edan, dan Dag Dig Dug karya Putu Wijaya yang meliputi: (a) kebebasan, (b) kecemasan, (c) kegagalan, (d) kesia-siaan, (e) kematian, (2) mendeskripsikan absurdisme dalam drama Aduh, Edan, dan Dag Dig Dug karya Putu Wijaya yang meliputi: (a) bunuh diri filosofis, (b) sifat simbolik, (c) tragedi dan komedi. Penelitian ini berfokus pada (1) eksistensialisme dalam drama Aduh, Edan, dan Dag Dig Dug karya Putu Wijaya yang meliputi: (a) kebebasan, (b) kecemasan, (c) kegagalan, (d) kesia-siaan, (e) kematian dan (2) absurdisme dalam drama Aduh, Edan, dan Dag Dig Dug karya PutuWijaya yang meliputi: (a) bunuh diri filosofis, (b) sifat simbolik, (c) tragedi dan komedi. Penelitian yang berpendekatan kualitatif ini, menggunakan metode pengumpulan data penelitian deskriptif kualitatif. Metode deskriptif adalah metode yang berupaya mendeskripsikan suatu gejala, peristiwa yang terjadi saat itu. Dalam penelitian ini metode deskriptif digunakan untuk mendeskripsikan konsep eksistensialisme dan absurdisme. Data penelitian ini menggunakan teorieksistensialisme dan absurdisme dalam drama karya PutuWijaya. Dengan menggunakan teknik dengan sumber data berupa tiga drama, teknik pengumpulan data yang relevan adalah teknik baca, simak, catat (BSC). Membaca dalam kegiatan pengumpulan data teks drama dilakukan dengan cara member perhatian yang benar-benar berfokus pada objek. Membaca dan menyimak adalah serangkaian teknik untuk memperoleh data yang valid dengan diikuti kegiatan mencatat data. Penelitian ini menyimpulkan lima konsep eksistensialisme dan tiga konsep absurdisme. Hasil penelitian menunjukkan bahwa eksistensialisme dalam drama Aduh, Edan, Dag Dig Dug karya Putu Wijaya, tampak Pada segi kebebasan, kecemasan, kegagalan, kesia-siaan, dan kematian.Tiga konsep absurdisme dalam drama Aduh, Edan, Dag Dig Dug karya Putu Wijaya tampak melalui bunuh diri filosofis, sifat simbolik, tragedi dan komedi.
\end{abstract}


Kata Kunci: kebebasan, kekecewaan, kegagalan, kesia-siaan, kematian, bunuh diri filosofis, sifat simbolik, tragedi dan komedi

\begin{abstract}
This study aims to (1) describe the existential drama Oh, Edan, and Dag Dig Dug works of Putu Wijaya which include: (a) freedom, (b) anxiety, (c) the failure, (d) the futility, (e) death, (2) describe absurdism in drama Ah, Edan, and Dag Dig Dug by Putu Wijaya which includes: (a) suicide philosophical, (b) the nature of the symbolic, and (c) of tragedy and comedy. This study focuses on (1) existentialism in the drama Oh, Edan, and Dag Dig Dug by Putu Wijaya which include: (a) freedom, (b) anxiety, (c) the failure, (d) the futility, (e) death and (2) absurdism in drama Ah, Edan, and Dag Dig Dug. This study is qualitative research, using descriptive qualitative research data collection. Descriptive method is a method which seeks to describe a phenomenon, the events that occurred at that time. In this study, descriptive method is used to describe the concept of existentialism and absurdism. This research data use existantialism theory and absurdism in playwrights by PutuWijaya. By using the technique with the data source in the form of three plays, the relevant data collection technique is a technique read. Reading the drama text data collection activities conducted by member's attention totally focused on the object. Reading and listening is a set of techniques to obtain valid data followed by activities recorded data. This study concluded five concepts of existentialism and three concepts of absurdism. The results showed that existentialism in the drama Oh, Edan, Dag Dig Dug by Putu Wijaya, looked in terms of freedom, anxiety, failure, futility, and death. Three absurdism concepts in drama Ah, Edan, Dag Dig Dug by Putu Wijaya looked through suicide philosophical, symbolic nature, tragedy and comedy.
\end{abstract}

Keywords: freedom, anxiety, failure, furtility, death.

\title{
PENDAHULUAN
}

Karya Putu Wijaya yang tidak pernah berhenti mengalir sejak tahun 1964 hingga kini baik cerkak maupun drama.Tentu harus dicatat oleh dunia sastra Indonesia, Lebih-lebih karena karya tersebut menunjukkan 
kualitas yang membanggakan. Putu menyatakan bahwa dalam bercerita ia memilih anekdot. Hal-hal lucu, remeh, aneh, kadang kala tak masuk akal.la mendapatkan ide dari tokoh-tokoh film kartun; bertolak dari hal-hal yang naï, sederhana, lugu, terang-terangan, penuh humor. Pada film kartun ada dua dimensi dan tidak pernah ada kematian, setiap tokohnya elastis. Semua itu dimaksudkan untuk menyulut, menghidupkan, mengagetkan, mencubit, menarik perhatian, mengganggu, meneror orang supaya berhenti sebentar dan berfikir bahwa ia juga manusia biasa seperti yang lain.

Putu juga mengakui bahwa ia gemar akan hal-hal yang samar, karena ia berpendapat bahwa di tengah kehidupan kita banyak sekali halhal samar, tidak jelas, dan semrawut. la beranggapan pula bahwa di Indonesia ini sebenarnya hal-hal yang absurd merupakan makanan seharihari yang konkret. Sebab kita berhasil hidup dengan santai dalam hujan peluru, bagaikan kelelawar yang dikaruniai radar dan terbang ngawur tanpa ketanggor apa-apa.

Sebagai seorang pengarang, Putu juga memperhatikan hal-hal seputar sastra. Terhadap persoalan sastra kontekstual yang menyerang sastra universal, ia beranggapan bahwa persoalan tersebut muncul akibat kecurigaan terhadap nilai sastra yang menggunakan tolok ukur keterpencilan; sastra yang dianggap berbobot kalau 'terpencil' dan sastra 'terpencil' itu adalah sastra yang dihasilkan oleh pengarang-pengarang intelektual di Jakarta. Putu sendiri berpendapat, sastra kontemporer yang baik sulit dibayangkan tidak kontekstual dan sekaligus tidak universal.

Fakta lain yang menarik untuk disimak adalah bahwa sejumlah lakon pada waktu itu mengingatkan kita pada (ciri) drama eksistensialsme dan absurd, satu jenis drama yang berkembang di Barat sejak pasca perang 14 | ISSN: 22477-5150 http://journal.unesa.ac.id/index.php/jpi 
dunia II. Ada kemungkinan para penulis lakon dan aktivis teater pada waktu itu 'terpengaruh' oleh masuknya drama eksistensialisme dan absurd ke Indonesia. Perlu diketahui bahwa sejak 1960-an telah ada sejumlah dramawan yang menerjemahkan dan mementaskan drama eksistensialisme dan absurd. Jim Adilimas misalnya, pada tahun 1960-an telah mementaskan 'Biduanita Botak' yang diadaptasi dari salah satu karya Ionesco. Juga Rendra telah mementaskan 'Menunggu Godot.' Ciri lain yang juga menonjol adalah hadir dan kentalnya unsur humor dalam lakon yang ditulis pada waktu itu yang segera mengingatkan kita pada cirri teater rakyat di Indonesia.Warna absurd dan eksistensialisme yang hadir dalam lakon-lakon pada waktu itu teraduk sedemikian rupa dengan humor sehingga membentuk sajian yang khas dan unik (Purnamasari, 2013).

Jadi, sebetulnya warna eksistensialisme dan absurdisme memang ada dalam lakon-lakon tahun 1970-an di Indonesia. Dalam lakon yang ditulis Putu Wijaya seperti Edan, Aduh, Dag Dig Dug, eksistensialisme dan absurdisme itu tampak. paling tidak kalau dilihat dari penggambaran tokoh-tokohnya yang cenderung tidak beridentitas dan barangkali juga plotnya.

Ciri khas lakon Putu Wijaya nampak, baik dari aspek struktur maupun tekstur. Penokohan dalam lakon Edan, sebagai salah satu unsur eksistensi. Tokoh tidak memiliki identitas yang jelas: hal ini dapat dijumpai dalam lakon-lakon Putu Wijaya seperti Aduh, Edan, dan Dag Dig Dug."Banyak sastrawan, dramawan, peminat lakon/teater yang membicarakan lakon Aduh, Edan dan lakon Dag Dig Dug karya Putu Wijaya, ada pula yang membicarakan pementasannya. Kehadiran Putu 
menarik untuk diketahui, bagaimana dia memenangkan sayembara lakon DKJ.

Lakon Aduh pernah mendapatkan juara I pada sayembara pada penulisan lakon kedua DKJ pada tahun 1973. Lakon Edan merupakan lakon Indonesia mutakhir sebab diciptakan sesudah tahun 1967. Lakon Edan dikatakan sulit dipahami, tetapi menarik karena berhasil memenangkan hadiah pertama sayembara penulisan naskah lakon yang diselenggarakan oleh Dewan Kesenian Jakarta tahun 1976. Di tahun1974 Putu Wijaya memenangkan berturut-turut juara satu dalam Sayembara Penulisan Naskah Lakon yang diadakan oleh DKJ dengan judul Dag Dig Dug. Sejak saat itu karya-karya drama Putu Wijaya seakan-akan menjadi ukuran bagi mereka yang akan menulis naskah drama kontemporer. Ciri khas karyanya yaitu cenderung menggunakan gaya atau metode obyektif dalam pusat pengisahan dan gaya stream of consciousness dalam pengungkapannya. Maksudnya, cara mendekati tokoh, Putu seperti tidak pernah menyentuhnya. Seolah-olah tokoh dibiarkan bergerak dengan tindakan dan pikiran- pikirannya, tak ubahnya seperti orang yang mengamati gerakgerik ikan di dalam akuarium (Abdullah, 1985:9).

Menurut Atmaja (Sumardjo, 1994:9), ide yang mendasari perubahan karya-karya Putu Wijaya adalah konsep psikoanalisis dan absurdisme. Putu Wijaya sendiri mengaku bahwa konsep kepengarangannya adalah "teror mental", usaha untuk memberikan pencerahan dengan kejutan, dengan pematahan atau pembalikan yangtiba-tiba (Wijaya, 2003:213). Sebagai pemain, Putu Wijaya sejak tahun 1991 bersama Teater Mandiri memainkan pertunjukkan tidak lagi menggunakan dialog tetapi gerak, bunyi danseni rupa (Wijaya, 2003:218). Kelebihan naskah drama Dag Dig Dug dibanding dengan naskah-naskah 16 | ISSN: 22477-5150 http://journal.unesa.ac.id/index.php/jpi 
drama PutuWijaya yang lain. Naskah-naskah drama Putu Wijaya biasa berdurasi antara 90 sampai 120 menit. Tak pernah lebih panjang dari itu, kecuali Dag Dig Dug. Teater Mandiri sampaisekarang belum pernah memainkan naskah itu (Wijaya, 2003:218). Lakon Dag Dig Dug tidak pernah dimainkan, karena Putu Wijaya tidak punya aktor kuat di dalam kelompok teaternya (Teater Mandiri). Naskah tersebut memerlukan minimal dua pemain yang hebat, agar mampu mengangkat peristiwanya (Wijaya, 2003:213).

Lakon yang bergaya absurd dan eksistensialisme, ternyata tidak hanya sekedar mewujud dalam bentuk, betapapun tokoh seperti Wietkiewics menstudi secara khusus bentuk atau form. Untuk mendapatkan kejelasan lebih jauh, kita harus mencermati pemikiranpemikiran orang-orang teater yang pada dasarnya adalah filsuf. Mereka itu antara lain Jean Paul Sartre (1905-1980) dan yang tak kalah pentingnya adalah Albert Camus (1913-1960). Kedua filsuf, sastrawan, dan dramawan dari prancis ini harus kita perhitungkan pandangannya dan karyanya sebab sebelum lakon mereka yang pengamat sering disebut realis, sudah menawarkan tema-tema absurd dan eksistensialis. Ini artinya, lakon-lakon absurd kiranya tak cukup diselesaikan dengan pengamatan bentuk, tetapi juga pandangan-pandangan, vison de monde atau weltanschauung atau world view, sungguh harus dilihat. Sartre melihat bahwa drama adalah suatu potret suatu proses keterlibatan, bukan dengan sibuk mempersoalkan fakta, tetapi 'hak' yang harus menunjukkan bahwa setiap tokoh, "bereaksi karena ia terlibat dalam suatu tindakan riskan (mengandung resiko) karena ia merasa yakin bahwa ia berhak untuk menjalankan pilihan itu" (Damono, 2007: 24). 
Gatra eksistensialisme dan absurdisme sudah masuk di Indonesia sejak awal 1960-an. Akan tetapi, konsep, filsafat, atau idiologi eksistensialisme dan absurdisme belum tampak benar. Baru pada awal 1970-an tatkala Bengkel Teater pimpinan Rendra memainkan Menunggu Godot, yang kemudian disusul dengan munculnya Aduh, sebagai lakon eksistensialisme dan Absurd di Indonesia mantap pertama, orang melihat bahwa teater realisme sudah benar-benar mulai mendapat tandingan, jika tidak boleh dikatakan sudah mulai ditinggalkan. (Damono, 2007: 38).

Sejak Putu Wijaya menang berturut-turut sebagai juara pertama dalam penulisan lakon yang diadakan oleh Dewan Kesenian Jakarta tahun 1973 (Aduh), tahun 1976 (Edan), dan Tahun 1974 (Dag Dig Dug). Sejak tahun tersebut nama Putu Wijaya semakin popular. Dia mempunyai ciri khas dalam menyajikan karya-karyanya. Ciri khas tersebut dapat dilihat dalam ketiga lakon tersebut diatas.

Dalam perkembangan lakon Indonesia modern, pembaharuan dibidang bentuk dan corak sangat menarik. Istilah eksistensialisme dan absurdisme mewarnai lakon Indonesia modern. Dalam hal ini DKJ mempunyai andil yang besar dalam pembaharuan ini, karena mampu merangsang sastrawan/dramawan untuk berkarya dan bersaing melalui sayembara. Ternyata sayembara telah mampu melahirkan warna baru dalam lakon Indonesia. Melalui sayembaralah ditemukan potensi-potensi baru dalam penulisan lakon. Disamping itu, sayembara melalui pemberian hadiah yang kurang lebih pengakuan berfungsi dalam menyongsong reputasi seorang pengarang secara lebih meluas."

Aduh, Edan, dan Dag Dig Dug sebagai lakon Indonesia modern menarik untuk diteliti. Ada keinginan mengetahui lebih jauh apa keistemewaan lakon ini. Benarkah lakon Aduh, Edan dan, Dag Dig Dug 18 | ISSN: 22477-5150 http://journal.unesa.ac.id/index.php/jpi 
pantas mendapatkan hadiah pertama atau juara satu karena bermutu? Dapatkah dibuktikan dari aspek eksistensialisme dan Absurdisme?

\section{METODE}

Penelitian tentang eksistensialisme dan absurdisme dalam drama karya Putu Wijaya termasuk kajian teks tekstual, yaitu kajian yang difokuskan pada teks yang ada di dalam drama karya Putu Wijaya. Oleh karena itu, metode yang penelitian yang sesuai adalah metode penelitian deskriptif kualitatif Ratna (2009: 58). Metode deskriptif yang dimaksud adalah metode yang berupaya mendeskripsikan suatu gejala, peristiwa yang terjadi saat itu. Dalam penelitian ini metode deskriptif digunakan untuk mendeskripsikan konsep eksistensialisme dan absurdisme. Metode kualitatif yang dimaksudkan bahwa dalam penelitian ini data bukan berupa angka yang teknis analisisnya menggunakan statistik tetapi berupa pemberian kata-kata. Data yang dimaksud dalam penelitian ini adalah kata-kata yang terdapat dalam drama karya Putu Wijaya yang berhubungan dengan eksistensialisme dan absurdisme. Metode dalam penelitian ini diharapkan mampu mencegah timbulnya penyimpangan pengumpulan data yang diperoleh data objektif (Jabrohim, 2000; Endraswara, 2011; 2012).

\section{HASIL DAN PEMBAHASAN}

Berdasarkan kenyataan di atas, maka eksistensialisme dan absurdisme dalam penelitian ini dikaji berdasarkan bentuk.

\section{Kebebasan}

Kebebasan bukan sesuatu yang harus dibuktikan atau dibicarakan, 
tetapi suatu realitas yang harus dialami. Kebebasan manusia yaitu bebas memilih diantara kemungkinan. Kemungkinan yang ada, menetapkan keputusan-keputusan serta bertanggung jawab tentang semua itu. Dialog yang dominan dalam drama Aduh ada dalam tokoh Salah Seorang dan Yang Berani, sebagai sosok eksistensialisme ia menganut kebebasan.

Dalam diskursus mengenai kebebasan diantara kaum eksistensialisme Sartre adalah yang paling radikal dalam merumuskan doktrin kebebasan. Bahkan dalam sejarah pemikiran barat.Manusia adalah bebas, manusia adalah kebebasannya. Tidak ada yang membatasinya dan membelenggu manusia baik keduniaan maupun ketuhanan. Kebebasan manusia adalah absolute dengan konsekuensi pertanggungjawaban individual terhadap perilaku-perilaku, pemikiran-pemikiran, dan situasinya sendiri adalah juga absolute (Abidin, 2006: 201).

Muncul tokoh perintis, didahului petunjuk dari nebentext, yang berbunyi demikian; (Salah seorang berlari keluar hendak merintis jalan). Kemudian, muncullah tokoh Perintis yang berteriak, 'Tunggu (keluar) aku merintis jalan' (Wijaya: 23). Dengan teks seperti ini, siapapun yang muncul di pentas dalam produksi lakon ini dapat menjadi siapa saja.

Menurut Sartre, manusia adalah kebebasan dan hanya dengan kebebasan ia bisa bertanggung jawab (Hassan,1992:139). Sartre kemudian melanjutkan penjelasannya dengan mengatakan bahwa dalam setiap tindakannya, manusia harus memilih proyek-proyek yang fundamental untuk hidupnya. Di sinilah manusia mendapatkan kebebasannya. Manusia bebas memilih proyek-proyek tersebut sesuai dengan kehendaknya.

(1) (pemimpin berjalan-jalan meninggalkan yang kesurupan itu menyesal. Kelompok ini mulai tidur. Pemimpin berjaga-jaga, memeriksa keadaan sekeliling lalu menghampiri mayat. Tergerak hatinya untuk mencuri. Setelah memeriksa keadaan, merasa aman ia mulai melepaskan cincin yang mati. 
Kemudian yang lain-lainnya juga. Sementara itu di kejauhan perintis jalan sedang sibuk merintis.)

(Wijaya, Ad/1973: 25)

Bahwa ada yang mencuri barang milik orang yang tidak mempunyai apa-apa. Adanya tindakan bebas oleh si tokoh untuk mencuri, setelah melihat keadaan aman. Hal ini adanya dorongan eksistensi pada diri tokoh untuk mengambil cincin. Pemimpin tega mencuri barang-barang milik kelompok tatkala ada kesempatan.

Para eksistensialisme secara umum menekankan pentingnya kebebasan manusia dan pilihan kreatif yang bebas. Kebebasan manusia ini muncul dalam eksistensialisme sebagai konsekuensi logis dari pernyataan existence precedes essense yang berarti penegasan subyektifitas yang tidak di dahului oleh sesuatu yang disebut human nature atau juga skema rasional tentang realitas. Pada babak satu tema dapat diketahui pada dialog yang diucapkan oleh tokoh-tokohnya.

(2) YANG KALAP: Kamu mau seenak perut sendiri saja. Lihat dong kami sedikit, tetangga di depan pantat kamu sendiri kamu gobrak, sialan! Katanya kita masih saudara, saudara tai buktinya kamu gebrak saja hantam kromo, apa namanya itu kalau bukan bar-bar, ya tidak! Kamu bukan Cuma kotor, jahat tapi biadab!

PENGUNTIT: Mengapa mereka punya hak lebih tinggi, begitu santainya saja memakan kita mentah-mentah.

YANG KALAP: Kalau kita diganyang, mereka akan ganyang kita (Wijaya, Ed/1976: 6)

Data (2) Yang Kalap mengalami kebebasan dengan memakan daging manusia tanpa rasa takut dan beban. Yang Kalap bebas memakan yang ingin di makannya, ia makan dengan santai seperti memakan nasi atau roti pada kehidupan umumnya. Tanpa melihat dan memperdulikan orang lain yang ada. Tidak ada perasaan yang menghantui dirinya dan seolah-olah apapun yang dilakukannya adalah bebas. 
Adegan enam berakhir setelah ketiga pengintai mengaku bahwa mereka juga telah ikut memakan daging korban dari kelompok bersenjata. Semua memperhatikan bungkusan itu. Dengan diawali oleh Pengintip yang mulai memakan daging, membuat para tokoh lainpun ikut juga meramaikan perbuatan yang berdosa itu. Pengintainya maju dan mengambil kembali.

(3) PENGINTAI:..yang harus dilakukan adalah langsung membuka, menyentuh, melihat, meraba, mengecap, menelan, dan mencintainya. Seperti ini (dengan tenang membuka bungkusan dan memulai makan isinya).

Semua orang takjub melihat pengintai itu makan.Akhirnya mereka mendekat.Merubung.

PENGINTAI: Mari makan silahkan, kalu ini dosa biar saya menanggung hukumannya, paling sedikit kamu tahu nanti ini terkutuk atau enak.

Mula-mula semua malu-malu, tetapi kemudian dengan segan-segan akhirnya semua ikut mengerumuni pengintai dan ikut makan.Suara pertempuran di kejauhan menghebat lagi. Di kejauhan terdengar seseorang berteriak-teriak. Ini adalah orang yang menyusul pengintai pertama yang hendak mengembalikan curiannya.la berseru-seru minta tolong sembari muntahmuntah.

(Wijaya, Ed/1976: 9)

Data (3) Adegan tujuh pada babak kedua yang membuat kejutan (surprise), karena ternyata kedua kelompok tersebut pada akhirnya sama. Yaitu sama-sama mau memakan daging manusia.Pengintai dengan bebas membuka bungkusan itu dan dengan bebas pula menyentuh sampai menelan daging itu. Kebebasan yang dilakukan akhirnya mampu mempengaruhi yang lain untuk ikut sama-sama memakan daging manusia.

Kebebasan bukan sesuatu yang harus dibuktikan atau dibicarakan, tetapi suatu realitas yang harus dialami. Kebebasan manusia yaitu bebas memilih diantara kemungkinan. Kemungkinan yang ada, menetapkan keputusan-keputusan serta bertanggung jawab tentang semua itu. 
Kebebasan menurut May (1993: 179) adalah kemampuan untuk berpartisipaasi dalam perkembangannya sendiri. Kebebasan merupakan potensi untuk membentuk diri sendiri dan merupakan sisi lain dari kesadaran seorang terhadap diri sendiri. Kebebasan ini ada dalam dialog Suami dan istri.

Permasalahan yang muncul adalah tentang kebebasan pemilihan nama tukang. Suami Istri mencari seorang tukang yang sekiranya layak untuk membuat kuburan yang tampak dalam dialog di bawah ini.

(4) SUAMI: Cari pelan-pelan saja. Keduanya diam dan minum.

ISTRI : Amak Baljun?

SUAMI: Dia sibuk!

ISTRI : Zubaidi?

SUAMI: Kurang berpengalaman

ISTRI : Syu'bah?

SUAMI: Lebih baik yang lain!

ISTRI : Karto Kadri?

SUAMI: Terlalu tua!

ISTRI : Samiun Tabak!

SUAMI: Makelar!

ISTRI : Sardono? Dia juga makelar.

SUAMI:Danarto...akan menasehatkanmu beli marmer

ISTRI : Susilo?

SUAMI: Sakit-sakitan!

ISTRI : Kadri? Terlalu muda?

SUAMI: Tidak akan mau!

ISTRI : Lalu?

SUAMI: Ibrahim?

ISTRI : Hah! Hah!

SUAMI: Siapa lagi kalau semua hah- hah- hah!

(Wijaya, Dg/1994: 44)

Percakapan pada data (4) begitu bebas memunculkan sebuah nama. Tidak ada batasan sampai muncul sepuluh nama yang terlontar dari Suami. Setiap usulan nama yang terlontar selalu ditolak. Begitu banyak alasanalasan yang membuat mereka kesulitan dalam menentukan nama tukang 
yang layak guna membangun sebuah makam untuk mereka. Hal ini sangat jelas kebebasan yang ada begitu melekat pada dialog Suami dan Istri.

Kebebasan dari data tersebut merupakan kebebasan yang ada pada drama Putu Wijaya. Hal ini ditandai dengan nama tokoh yang bebas, dialog yang bebas, kebebasan menentukan keputusan, tokoh tanpa adanya batasan antar tokoh. Kebebasan dalam drama Dag Dig Dug lebih dominan dibanding dalam drama Aduh dan Edan karena kekuatannya terletak hanya pada kedua tokoh yaitu Suami dan Istri.

\section{Kecemasan}

Dalam kehidupan setiap manusia pasti mengalami rasa cemas. Kecemasan adalah respon terhadap situasi tertentu yang mengancam, dan merupakan hal yang normal terjadi menyertai perkembangan, perubahan, pengalaman baru atau yang belum pernah di lakukan, serta dalam menemukan identitas diri dan arti hidup. Kecemasan adalah reaksi yang dapat dialami siapapun. Kecemasan merupakan suatu perasaan subjektif mengenai ketegangan mental yang menggelisahkan sebagai reaksi umum dari ketidak mampuan. Begitu pula yang dialami oleh Salah Seorang ketika merasa terdesak oleh keadaan untuk segera menentukan keputusan yang tepat.

(5) SALAH SEORANG: Kita dituduh lagi seperti dulu. Cepat kita terdesak

SALAH SEORANG : Salah sedikit kita bisa hancur. Tentukan cepat, tidak ada waktu. Kita terdesak

(Wijaya, Ad/1973: 10)

Kutipan tersebut menunjukkan beberapa hal penting. Pertama, orang-orang yang bergerombol itu ternyata pernah mengalami sesuatu yang menjadikan mereka traumatik, 'dituduh seperti dulu.'Kedua, mereka 
merasa terdesak, dan ketiga, mereka 'tidak ada waktu.'Rasa cemas muncul dalam perasaan tertindih, dapat muncul berbagai bayangan yang menakutkan dalam benak seseorang, misalnya bahwa seakan-akan mereka melihat makhluk halus.

Kecemasan disuatu pihak adalah suasana hati dasariah yang menyingkapkan keterlemparan Dasein, dan dilain pihak adalah suasana hati yang timbul dengan latar belakang tersingkapnya keterlemparan itu dalam suatu momen eksistensial. Orang-orang tersingkir yang tidak berhak mengatakan tidak bersalah. Di samping itu, mereka takut sekali kalau ditangkap polisi, bahkan sangat takut kepada peronda.

(6) PERINTIS :'Kenapa? apa yang kau takutkan? ulat? bau? ulat kan hanya ulat, bau kan hanya bau. Ayo, ini sudah lewat pukul tiga, kita bisa tertangkap orang peronda. Mau masuk penjara? kan bukan kita yang membunuhnya...

(Wijaya, Ad/1973: 27)

Kutipan data (6) memberikan dukungan penegasan bahwa kelompok itu bukanlah orang-orang yang dilindungi hukum. Mereka, seperti banyak terjadi dalam kasus di masyarakat, dengan serta merta menjadi kambing hitam. Adanya kecemasan yang menghantui dengan pertanyaan dan jawaban yang dilontarkan oleh Perintis.

Kecemasan yang muncul pada data (6) disebabkan karena ada rasa tidak percaya dan curiga. Untuk itu guna meyakinkan meraka, Yang ngibul menyuruh mereka untuk berterus terang dengan berhadapan dengan mereka yang modal tubuh. Dengan rasa cemas itu akhirnya mampu membuat mereka melakukan perbuatan membuka baju, guna meyakinkan mereka untuk bersikap jujur. Seandainya mereka tidak takut dan tidak cemas, maka perbuatan itu tidak akan terjadi. 
Kehadiran Wakil muncul kembali dengan adanya suara bersinbersin dari kelompok pemakan. Suara bersin tersebut berhasil membangkitkan kemarahan kelompok penguntit sehingga sampai melakukan kekerasan dengan menampar tokoh lain.

(7) PENGUNTIT: Pantas, baunya tak sedap (mendekatkan hidungnya) seperti bau apa ini ya (mendekatkan hidung ke mulut orang itu bersin). Bajingan! (langsung menampar).

PENGUNTIT: Jangan! (memegang kawannya). Maaf, sumpah mati kami tidak bermaksud melakukan kekerasan itu, tadi gerak refleknya (orang itu bersin lagi). Bangsat! (menampar). Dikasih hati melonjak (mendorong yang makan itu).

(Wijaya, Ed/1976: 4)

Pada data (7) kelompok makan itu mulai lagi makan barang-barang bukti itu tanpa berusaha menguraikan buntalannya. Mereka tampak begitu tenang kembali sehingga para penguntit itu cemas lagi. Kecemasan itu pun muncul karena ada bau tak sedap yang melekat pada hidungnya.

Kecemasan disuatu pihak adalah suasana hati dasariah yang menyingkapkan keterlemparan Dasein, dan dilain pihak adalah suasana hati yang timbul dengan latar belakang tersingkapnya keterlemparan itu dalam suatu momen eksistensial. Kecemasan berkaitan dengan ada. Rasa cemas menghempaskan kita pada eksistensi kita di dunia ini, yaitu menyingkap bahwa kita ini ada untuk kemungkinan kita sendiri (Sein zum eigensten seinkonnen).Jadi kecemasan menguak kebebasan eksistensial kita. Kita cemas karena menyadari kebebasan kita, dan kita bebas dalam kecemasan itu (Heidegger, 2003: 77).

Perang batin muncul antar tokoh gara-gara uang. Dalam pemikiran mereka seandainya saja apa yang mereka lakukan dilihat dan diketahui oleh orang lain, maka rasa malu yang tak terhingga menyelimuti Suami Istri 
Engkin Suwandana, Eksistensialisme dan Absurdisme...(hal. 12 - 46)

itu. Kecemasan itu terus ada karena dihantui rasa ketakutan yang mendalam.

(8) SUAMI: (Menghitung)....kembalikan, tidak, kembalikan, tidak, kembalikan, tidak, kembalikan, tidak kembalikan. TIDAK...kembalikan, ah!

ISTRI : Hhhhhhh!

SUAMI: (sesudah lama diam) Jadi?

ISTRI : TERSERAH!

(Wijaya, Dg/1994: 21)

Dalam data (8) kecemasan pada Suami semakin menguat, karena dalam hatinya selalu muncul pertentangan antara kembalikan dan tidak. Istripun tidak mampu membantu menghilangkan rasa cemas sang Suami. Hal ini dibuktikan dengan sang Istri hanya mampu memberikan jawaban terserah.

Berdasarkan analisis tersebut, Kecemasan pada drama Putu Wijaya ditandai dengan perasaan tertindih, ketakutan, ketidakpercayaan dan curiga, kebingungan pada tokoh, perang batin yang terdapat pada dialog. Kecemasan dalam drama Edan dan Dag Dig Dug lebih dominan dan kecemasannya terlihat dalam segi psikis dari masing-masing tokoh.

\section{Kegagalan}

Kegagalan dalam perspektif eksistensialisme berarti kegagalan manusia dalam usaha mengada, menjadi dirinya secara utuh. Kegagalan merupakan bagian dari kehidupan manusia, karena manusia selalu berhadapan dengan keterbatasan-keterbatasan, baik yang berada pada diri sendiri maupun di luar dirinya. Eksistensi gagal muncul jika dalam usaha untuk menjadi pribadi yang utuh tidak tercapai. Apabila dikaitkan dengan kebebasan, eksistensi kegagalan semakin jelas terlihat karena kebebasan itu pada akhirnya harus berhenti di suatu titik (Camus, 1999: 
22). Begitu pula dalam drama Aduh, dialog ini mengalami kegagalan yang terdapat pada nebentext sebagai berikut:

(9) (Sekelompok orang sedang melakukan kegiatan. Mereka tiba-tiba menghentikan kegiatannya tatkala terdengar suara sirine. Sayup-sayup kemudian bertambah santer dan pada akhirnya memekakkan. Orang-orang tersebut menunggu. Perlahan-lahan jerit sirine itu lampau. Lalu terasa kosong. Orang-orang itu berpandang-pandangan. Salah serang tertawa. Beberapa yang lainnya mengikuti. Kemudian mencoba menyambung kegiatannya kembali. Tetapi. Hal tersebut tidak dapat dilaksanakan karena ada seseorang yang datang. la berselimut dan tampak sakit lahir dan batin. la muncul seperti hendak mengadukan nasibnya pada kelompok itu. Hal ini menggerakkan salah seorang dari keompok itu untuk bertanya: "Kenapa? Yang sakit menunjukkan sakitnya semakin sarat. Salah seorang yang lain kemudian mengajukan pertanyaan: "kenapa?, sakit ya? Yang lain pun ikut bertanya: "sakit apa? Sakit apa? Karena si sakit tidak dapat menjawab, kelompok itu meneliti dengan seksama dengan penuh simpati. Kemudian untuk jelasnya mereka melanjutkan lagi pertanyaan-pertanyaan)

(Wijaya, Ad/1973: 3)

Pada data (9) Usaha untuk menyambung kegiatannya kembali tidak dilaksanakan karena ada seseorang yang datang. Di samping itu kegagalan juga tampak pada Si Sakit yang tidak bisa menjawab pertanyaan dari Salah Seorang. Ini merupakan bukti kegagalan dalam eksistensialisme.

Di sini dapat dilihat bahwa tegangan yang telah tercipta tersebut tiba-tiba menjadi menurun. Wakil yang diharapkan dapat mewakili kelompoknya untuk berunding dengan kelompok pemakan, kenyataannya justru, jika dipikirkan secara logis, mengucapkan kata-kata lucu bahkan konyol. Hal ini berlawanan sekali dengan sikap dan niat mereka semula untuk menyerang kelompok pemakan.

(10) Wakil kembali kepada kawan-kawannya.

PENGUNTIT : Terus dong sudah naik

WAKIL : Cukup, saya tidak kuat lama-lama bicara, habis ada kenalan di situ

PENGUNTIT : Peduli apa kenalan, ini kan perjuangan.

WAKIL : Soalnya masih ada hutang sama dia, malu ah. 
(Wijaya, Ed/1976: 9)

Perundingan pada data (10) yang dilakukan oleh kelompok penguntit tidak berhasil, bahkan bukti-bukti yang dibawa ikut dimakan oleh kelompok pemakan karena mereka telah kehabisan makanan.Mereka makan karena dalam keadaan terpaksa. Inilah kegagalan yang terjadi dalam dialog tersebut.Tidak adanya bukti membuat mereka gagal.

Kegagalan merupakan bagian dari kehidupan manusia, karena manusia selalu berhadapan dengan keterbatasan-keterbatasan, baik yang berada pada diri sendiri maupun di luar dirinya. Eksistensi gagal muncul jika dalam usaha untuk menjadi pribadi yang utuh tidak tercapai. Kegagalan adalah sebuah peristiwa yang biasa terjadi pada diri manusia. Kegagalan muncul karena manusia selalu dihadapkan pada keterbatasan diri. Selain itu, kegagalan muncul karena manusia adalah sosok yang terbatas. Kegagalan merupakan perwujudan bahwa sesuatu yang diharapkan oleh manusia tidak akan selamanya terpenuhi secara penuh.

(11) ISTRI : Buku catatan alamat Cairul

SUAMI: Jadi bukan surat. Tapi coba saja. Tapi ingat ini pelajaran lagi, lain kali jangan BERLAGAK tahu. Tunggu dulu. Aku ingat. Ya, Chairul, Chairul, Chairul Umam. Ia TIDAK PERNAH MONDOK di sini. Tapi dia sering datang ke mari. Agak pendek. Kumal, dekil, berbau. Matanya melotot. Tidak memperhatikan dirinya. Jarang mandi. Tapi serius, otaknya bukan main, pikiran-pikirannya sulit seperti benang kusut. Banyak orang mengaguminya.

ISTRI : itu kan Akhmad Wahid (suami berfikir keras)

SUAMI: Ya. Itu akhmad Wahid. (diam sejenak. Kemudian bersiul-siul lagi berfikirfikir). Kau sendiri juga belum ingat!

(Wijaya, Dg/1994: 22)

Dalam data (11) ketidakmampuan Suami untuk mengingat nama merupakan kegagalan, karena usahanya untuk mengingat sebuah nama 
tidak tercapai. Suami terus berfikir keras guna mengingat-ingat kembali, tapi masih juga belum ingat. Dengan demikian, Suami mengalami kegagalan dalam usaha mengingat nama.

Berdasarkan analisis tersebut, drama Putu Wijaya terdapat aspek kegagalan. Dalam hal ini ditandai dengan tidak bisa menjawab pertanyaan, tidak ada bukti dalam berunding, ketidakmampuan mengingat nama pada dialog antar tokoh. Yang mempunyai kekuatan adalah drama Dag Dig Dug karena aspek kegagalannya lebih banyak dibanding drama yang lain.

\section{Kesia-siaan}

Dia tidak dapat menemukan keberadaannya diri sendiri di dunia ini dan dia merasakan untuk apa dia berbuat adalah sia-sia dan tidak berarti. Dalam hal tidak berguna ini, dia tidak merasakan, tanpa takut, dan rasakan tidak ada kebimbangan, lebih dari itu di situ adalah tidak ada daya pisah pada semua. Rasa dari hal tidak berguna adalah perasaan dari berputusasa dan pesimisme (Alssid, 1964: 210). Kesia-siaan ini ada dalam tokoh Salah Seorang yang digambarkan sebagai berikut.

(12) SALAH SEORANG: Apa yang kita tunggu lagi?

SALAH SEORANG: Dari tadi kita tidak menunggu apa-apa

(Wijaya, Ad/1973: 11)

Dialog data (12) ada kata tunggu dan menunggu yang diucapkan oleh Salah Seorang. Sangat sia-sia yang dilakukan oleh Salah Seorang karena menunggu tapi tidak tahu yang ditunggu. Tidak ada kejelasan objek apa yang sebenarnya ditunggu. Salah Seorang sebenarnya sudah tahu kalau tindakannya untuk menunggu tidak ada artinya tapi meskipun demikian tetap saja dilakukan oleh tokoh itu. 
Rasa dari hal tak berguna adalah perasaan dari berputus-asa dan pesimisme (Alssid, 1964:210). Ini adalah karena akibat kerenggangan lengkap atau kerenggangan manusia itu awal untuk mengisi kehampaan hebat dan hal tak berguna. Pada babak ke dua adegan empat tentang membawa lari korban terdapat rasa kesia-siaan.

(13) Setelah korban itu diperebutkan di sekitar itu, kemudian mereka melarikannya jauh-jauh tanpa memutuskan talinya terlebih dahulu. Ada juga yang sebetulnya berusaha untuk memustuskan tapi entah kenapa tali itu tak bisa putus.

Korban itu dilarikan menjauh.

YANG NAIK : (makin pilu). Tolonggg, tolonggg

PENGANGKUT: Aneh, itu kawan mereka sendiri?

PENGANGKUT: Apalagi kalau salah satu diantara kita bagaimana ya?

(Wijaya, Ed/1976: 2)

Pada data (13) dengan di bawanya lari korban maka kesia-siaan itu ada. Hal ini karena masih terdapatnya tali pada diri korban. Secara otomatis tali itu melekat pada korban dan masih menyatu pada tubuhnya. Orang lari tetapi dalam tubuhnya masih terikat maka sangat sulit bagi dirinya untuk bisa bebas beraktivitas. Untuk itu tindakan yang dilakukan sangatlah sia-sia.

Kesia-siaan terlihat pada data (13) ketika Suami yang ingin membuat bangunan makam untuk dirinya, padahal mereka masih hidup. Ini merupakan tindakan tidak berarti. Makam merupakan tempat orang mati bukan tempat orang yang masih hidup. Tetapi Suami Istri ini berencana membuat makam untuk dirinya yang masih hidup. Seandainya bangunan sudah jadi, maka tidak ada yang menempati karena mereka masih hidup. Ini pun dipertegas dalam dialog di bawah ini.

(14) ISTRI : Orang belum tahu kapan mati kok sudah bikin kuburan SUAMI : Apa?

ISTRI : Pantas Ibrahim mengambil tali. Mau ngukur tanah ya! 


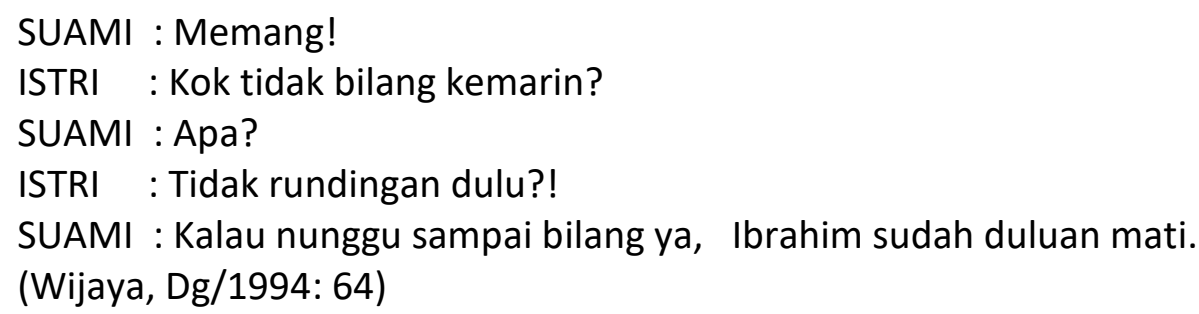

Data (14) menunjukkan Dia tidak dapat menemukan keberadaan dirinya sendiri di dunia ini dan dia merasakan apa yang dia berbuat adalah sia-sia dan tidak berarti. Orang masih hidup sudah menyiapkan kuburannya sendiri dengan tanpa berunding dengan yang lain, padahal belum tahu kapan dia mengalami mati.

Berdasarkan analisis tersebut, drama Putu Wijaya mempunyai aspek kesia-sian yang ditandai dengan tokoh yang menunggu, pengulangan peristiwa, kondisi capek, pembuatan makam. Hal ini merupakan kekuatan yang ada dalam ketiga drama Putu Wijaya karena saling terkait antara cerita dan alur.

\section{Kematian}

Kematian menurut Martin Heidegger merupakan suatu kejadian yang paling nyata (Lavine, 2003: 19). Adapun kematian bagi Sartre merupakan sesuatu ketidakberdayaan diri secara total. Kematian sama dengan kelahiran tidak ada namanya kejadian penting dan berarti dalam hidupku, bukan apa-apa selain mengisi eksistensiku sebagai makhluk sadar. Kematianku hanyalah saksikan atas ketidakmasukakalan eksistensi manusia (Lavine, 2003: 20).

Hubungan antara babak pertama, kedua, dan ketiga bersifat kronologis dan mengikuti pola linier. Cara menghubungkannya 
memanfaatkan peranan nebentext. Untuk menyambung babak pertama dengan babak kedua, nebentext menyajikan uraian sebagai berikut.

(15) Mayat itu masih di tempatnya semula. Kelompok itu menunggunya dengan setia tapi tak bisa berbuat apa-apa. Kegelapan ditempat itu berangsurangsur memecah karena cahaya bintang-bintang. Yang kesurupan menggeletak dekat mayat. la bergumam. Yang simpati menangis dalam gelap. Kelompok orang-orang itu berjongkok di kejauhan dengan sepi. Mereka pun kehilangan kepercayaan.

(Wijaya, Ad/1973: 10)

Nebentext petunjuk pelaksanaan produksi memberikan isyarat bahwa kelompok itu tetap berada di tempat yang sama. Kematian terlihat pada kata mayat yang ada dengan kelompok yang setia menungguinya. Dengan adanya kematian ada tokoh yang merasa kehilangan dengan tergeletak dan menangis.

Kematian selalu dan tidak sekali saja. Dimengerti secara eksistensial, tulis Heidegger, 'kelahiran tidak dan tak pernah merupakan hal yang telah lewat dalam arti tidak ada lagi, begitu juga kematian bukanlah hal yang belum ada...Dasein faktis bereksistensi dengan selalu lahir, dan mati dengan selalu lahir dalam arti ada-menuju-kematian.' (Heidegger, 2003:90).

Kematian merupakan kejadian nyata. Tak ada orang lain yang mampu mengubahnya ataupun menasehatinya. Sartre menyatakan bahwa "kalau kita mati, kematian itu bukan milik kita sendiri, melainkan untuk mereka yang kita tinggalkan." Merekalah yang memberi arti terhadap kematian kita, bukan kita sendiri. Adegan ini merupakan klimaks dari alur dramatik yang ada pada cerita ini. Lakuan menyusul menanjak, ketegangan memuncak melalui klimaks sehingga mencapai sebuah kematian. 
(16) PENGANGKUT: Di perutnya ada bekas tertancap, waktu dia tidak berhasil lari melompat pagar, sebab (menerangkan dengan gerakan tubuh, salah seorang kawannya menancapkan pagar ke perut). Kok satu, paling sedikit tiga!

PENGANGKUT: Empat ah (menambahkan) Beberapa orang mengambil tongkat dan menonjok-nonjok tubuh korban itu sehingga meronta-ronta.

MANDOR

: Terus, terus! Keras dikit!

PENCATAT : Ya, dan sebuah jari manisnya putus sehingga cincinnya lepas.

MANDOR : Laksanakan! (dilaksanakan).

(Wijaya, Ed/1976: 4)

Penggantungan korban pada data (16) yang dilanjutkan dengan penyiksaan oleh kelompok pengangkut dimaksudkan untuk membuktikan bahwa mereka menemukan korban dalam keadaan demikian. Di sini tampaklah kegilaan mereka dalam memecahkan masalah secara tidak masuk akal. Tragisnya kematian korban adalah sebuah petanda bahwa dengan adanya upaya pembunuhan dalam dialog itu. Setelah kelompok Pengangkut korban mencatat data-data korban, muncul Entah Siapa yang ikut masuk dalam persoalan.

Kematian menurut Martin Heidegger merupakan suatu kejadian yang paling nyata. (Lavine, 2003: 19). Adapun kematian menurut Sartre merupakan sesuatu ketidakberdayaan diri secara total. Kematian sama dengan kelahiran tidak ada namanya kejadian penting dan berarti dalam hidupku, bukan apa-apa selain mengisi eksistensiku sebagai makhluk sabar. Kematian adalah saksian atas ketidakmasukakalan eksistensi manusia (Lavine, 2003: 20). Kematian merupakan problematika yang tidak dapat dihindarkan. Kematian tersebut juga ada pada Chairul Umam. Suami mengingat tampangnya berkumis putih, dan hatinya baik.

(17) SUAMI: Dikubur keesokan harinya di Menteng Pulo. Di mana Menteng Pulo? Aku tahu kuburan di Jakarta yang bernama karet. (pause) ditabrak motor dari belakang. Kepala patah. Ditolong oleh kere-kere. Yang 
menabrak lari. Mulai lumrah sekarang. Motor terlalu murah, padahal berbahaya. Perlu selamatan?

ISTRI : Ah?

(Wijaya, Dg/1994: 11)

Dalam data (17) Suami menceritakan kejadian yang mengakibatkan Chairul Umam meninggal. Banyak peristiwa yang terjadi, mulai dari peristiwa kecelakaan sampai proses penguburannya. Semuanya diceritakan dengan rinci dan lengkap sesuai kejadian yang sebenarnya. Ini adalah bukti bahwa adanya kematian yang dialami oleh si tokoh yang bernama Chairul Umam.

Berdasarkan analisis tersebut, drama Putu Wijaya mengalami kematian yang ditandai dengan suasana ironis, proses penguburan dan kecelakaan, pembunuhan tragis yang terjadi pada tokoh. Kematian yang ada pada drama Aduh, Edan, Dag Dig Dug tidak disebabkan karena sakit tetapi karena adanya proses untuk membunuh dari orang lain. Kematian inilah yang mempunyai nilai kesamaan dari ketiga drama itu.

\section{Absurdisme dalam Drama Aduh, Edan, Dag Dig DugKarya Putu Wijaya}

Bunuh diri psikis artinya bahwa manusia jenis ini berakhir dengan rasionalitas. Dengan hanya menolak, tidak berbuat, dengan hanya membunuh sikap filosofi aslinya (Martin, 2001: 55). Bunuh diri filosofis terlihat dalam sambungan babak kedua dengan babak ketiga, nebentext menyajikan uraian sebagai berikut.

(18) Pagi hari,

Kelompok itu telah berkumpul di tempat semula, perintis jalan, yang satu dan yang lain tidak........tidak tampak. Dikejauhan terdengar suara-suara anjing seperti digoda oleh sesuatu.Kelompok itu mendengarkan suara itu dengan penuh perhatian.

(Wijaya, Ad/1973: 40) 
Nebentext yang memberikan petunjuk pelaksanaan produksi untuk babak dua dan tiga memberikan isyarat bahwa kelompok itu tetap berada di tempat yang sama. Pengulangan yang terjadi menunjukkan bahwa mereka tidak beranjak dari masalah maupun tempatnya. Hal ini manusia ditantang untuk menyelesaikan masalah, tapi kelompok hanya mendengarkan suara, sedangkan yang satu dan yang lain tidak berbuat apa-apa.

Bunuh diri psikis artinya bahwa manusia jenis ini berakhir dengan rasionalitas. Namun sebagaimana halnya bunuh diri, dewa-dewapun berbeda-beda seperti manusia. Ada beberapa cara untuk meloncat, tetapi yang penting adalah meloncat (Camus, 1999: 51-52).

Pengintai pertama tidak mau mengatakan apa yang telah dilakukan olehnya selama mengintai kelompok bersenjata; dia hanya menceritakan bahwa kelompok bersenjata telah memakan temannya sendiri.

(19) PENGINTAI: ....Wah kalau kamu lihat bagaimana laparnya mereka, bagaimana mereka persetankan semuanya. Tangan mereka mengamuk beramai-ramai, semuanya ingin bagian lebih banyak, sementara mulut mereka mulai terbuka lantas mengunyah daging kawannya sendiri. Lezat dan asyik!

(Wijaya, Ed/1976: 9)

Data (19) ditandai dengan adanya laporan dari pengintai pertama telah berhasil menaikkan klimaks dan kemudian diperkuat oleh Pengintai kedua. Melalui laporan pengintai kedua inilah, diperoleh kejelasan apa yang telah dilakukan oleh kelompok bersenjata yang telah membawa lari temannya (korban) yang telah ditembak itu.

(20) Pengintai yang lain muncul. Datang dengan mengendap-endap sambil menundukkan kepalanya.

SALAH SATU : Nah ini dia! Benar?

PENGINTAI : (Menundukkan kepalanya) Hmm (tak bisa ngomong).

SALAH SATU: Betul mereka makan mentah-mentah kawannya?

36 | ISSN: 22477-5150 http://journal.unesa.ac.id/index.php/jpi 
PENGINTAI :(Mengangguk, tapi terus tunduk). Hmm!

SALAH SATU :Barangkali mereka kerasukan setan!

(Wijaya, Ed/1976: 18)

Informasi yang diberikan oleh pengintai kedua dalam data (20) menimbulkan tegangan karena dia mengaku terus terang telah ikut memakan daging korban. Dengan adanya sebuah informasi dan pengakuan dari Pengintai, maka bunuh diri filosofis itu ada pada adegan ini. Secara otomatis maka akan mempengaruhi tokoh lain untuk mengetahui siapa yang memakan daging itu.

Bunuh diri psikis artinya bahwa manusia jenis ini berakhir dengan rasionalitas. Dengan hanya menolak, tidak berbuat, dengan hanya membunuh sikap filosofi aslinya (Martin, 2001: 55). Problematika dalam Suami terus bergejolak dengan sikap bunuh diri filosofinya. Dalam hati selalu ada pertanyaan-pertanyaan yang memberatkan keputusannya, sehingga muncul perasaan sulit untuk mengambil sebuah keputusan.

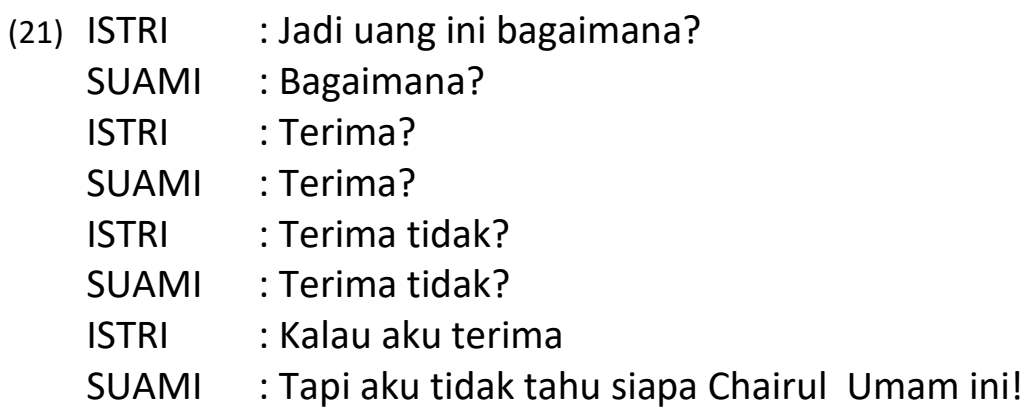

Penolakan yang dilakukan pada data (21) atas uang yang diberikan menimbulkan rasa untuk tidak bisa berbuat.Ini merupakan sikap bunuh diri filosofi karena ingin membunuh rasa yang muncul untuk menerima pemberian uang itu. Sulit untuk memutuskan antara rasa ingin menerima 
dan menolak. Sebenarnya mereka ingin menerima tapi karena tidak tahu siapa Chairul Umam membuat mereka untuk berfikir kembali.

Berdasarkan analisis tersebut, drama Putu Wijaya mengalami bunuh diri filosofis dengan ditandai dengan rasa tidak bisa berbuat, dan tindakan kontradiktif yang dialami tokoh dalam cerita. Drama Edan menjadi faktor penguat dalam aspek bunuh diri filosofis karena mempunyai makna yang lebih dengan jumlah yang banyak pula dibandingkan dengan drama Aduh dan Dag Dig Dug.

\section{Sifat Simbolik}

Semuanya bermakna simbolik belaka unsur 'cerita' yang tidak jelas di zaman dan tempat yang mana, kostum yang tak dikenal dalam kenyataan di luar pentas, tata laku yang karikatural dan simbolik, adegan slow motion, adegan still, peristiwa yang tak lazim (mayat memanjang atau makin berat) dan sebagainya. Semua tadi dikemukakan di pentas bukan untuk berbicara atas nama bentuknya, tetapi atas makna lain yang lebih abstrak dan hakiki (Damono, 2007: 59).

Dalam teks lakon Aduh ada kata-kata untuk nyanyian yang di nyanyikan oleh Perintis. Lagu itu terdiri dari tiga bait. Lewat sebuah lagu unsur simbol menyatu menjadi sebuah makna yang berarti, yang tidak bisa dipisahkan. Seluruh lagu itu terdapat unsur simbolik seperti tampak di bawah ini.

\section{(22) Kita semua lain}

Mereka semua lain

Karena sifat kita lain

Karena bentuk kita lain

Tetapi karena perut kita sama

Kita semua sama

Mereka semua sama

38 | ISSN: 22477-5150 http://journal.unesa.ac.id/index.php/jpi 


\author{
Karena nama kita sama \\ Karena otak kita sama \\ Tetapi mulut kita lain \\ Kita semua mm! \\ Kamu semua mm! \\ Karena adat kita $\mathrm{mm}$ ! \\ Karena sifat kita $\mathrm{mm}$ \\ Tetapi karena Anu kita mm. \\ (Wijaya, Ad/1973: 26)
}

Pada data (22) kalau nyanyian itu dicermati secara tekstual, tampaknya tidak menunjukkan apa-apa. Apabila ditilik lebih rinci, nyanyian itu menyarankan bahwa pada dasarnya manusia dimana-mana sama sekaligus saling berbeda. Pada bait ketiga, predikat sama dan berbeda dihilangkan dan diganti dengan ' $m m^{\prime}$. semacam gumam yang menunjukkan sulitnya menemukan kata yang tepat untuk mengatakan sesuatu.

Semuanya bermakna simbolik belaka unsur 'cerita' yang tidak jelas di zaman dan tempat yang mana. Bukan untuk berbicara atas nama bentuknya, tetapi atas makna lain yang lebih abstrak dan hakiki (Damono, 2007: 59). Sifat simbolik dapat dilihat dari sesuatu yang sekiranya dapat dijadikan simbol. Dalam dialog ini bau tak sedap merupakan simbol yang menjadikan hidung untuk bersin.

(23) PENGUNTIT: Pantas, baunya tak sedap (mendekatkan hidungnya) seperti bau apa ini ya (mendekatkan hidung ke mulut orang itu bersin). Bajingan! (langsung menampar).

PENGUNTIT: Jangan! (memegang kawannya). Maaf, sumpah mati kami tidak bermaksud melakukan kekerasan itu, tadi gerak refleknya (orang itu bersin lagi). Bangsat! (menampar). Dikasih hati melonjak (mendorong yang makan itu).

(Wijaya, Ed/1976: 4) 
Bau tak sedap pada data (23) merupakan sifat simbolik yang menyebabkan orang bersin, sehingga sampai ada yang menampar dan melakukan kekerasan. Penguntit sudah tahu kalau hidungnya sebenarnya mencium bau tak sedap tapi Penguntit malah mendekatkan hidungnya untuk mayakinkan dari mana bau itu sebenarnya. Tetapi setelah mencium bau itu malah hidungnya bersin-bersin.

Bermakna simbolik belaka unsur 'cerita' yang tidak jelas, berupa huruf atau abjad yang terlontar dalam dialog Suami Istri. Satu per satu huruf itu terucap hingga tersusun menjadi sebuah nama yang terdapat dalam dialog di bawah ini.

(24) SUAMI: O ya! Chairul, Chairul....ini U atau N

ISTRI : U!

SUAMI: Ini?

ISTRI : M!

SUAMI: Ini?

ISTRI : A. Ini M!

SUAMI: Seperti tulisan dokter.

(Wijaya, Dg/1994: 8)

Data (24) Suami itu tidak bisa membaca tulisan yang ada. Ada beberapa huruf yang di eja, guna meyakinkan nama Chairul Umam. Angkaangka itu muncul satu-persatu membentuk sebuah nama. Huruf yang dimaksud merupakan sifat simbolik dari penyempurnaan sebuah nama. Di samping itu ada simbol yang tampak pada dialog Suami Istri ketika terkejut karena seruan yang tiba-tiba.

(25) SUAMI : Ah!

ISTRI : Apa?

SUAMI : Merah. Tu, itu tanggalan. Sekarang kan rebo tanggal Dua Belas. Ya nggak?

ISTRI : Ah?

SUAMI : Pantas, Koran tidak terbit. Kantor tutup, (meletakkan tasnya di atas meja). Hah! Tertipu, goblok! Goblok.

(Wijaya, Dg/1994: 30)

40 | ISSN: 22477-5150 http://journal.unesa.ac.id/index.php/jpi 
Pada data (25), ada pernyataan tanggal merah yang merupakan sifat simbolik dari hari libur. Mereka lupa kalau ada tanggal merah. Untuk itu semua kantor dan kantor pos yang mau dituju untuk mengantar dan mengembalikan surat secara otomatis mengalami tutup.

Berdasarkan analisis tersebut, drama Putu Wijaya mengalami sifat simbolik yang ditandai dengan kejadian misterius, waktu, suara, nyanyian, angka abjad, bau, tanggal merah yang merupakan simbol pada dialog.Dalam hal ini drama Aduh menjadi kekuatan simbol Putu Wijaya sebagai ungkapan untuk mewakili prosesnya sebagai dramawan besar dengan menciptakan simbol-simbol yang ada disekelilingnya sebagai kekuatannya.

Tragedi dan Komedi

Teater rakyat Indonesia umumnya tidak mengenal pembagian 'tragedi' dan 'komedi'.Teater mutakhir baik yang berbentuk drama tradisional maupun drama modern, baik naskah drama maupun pertunjukkan drama telah mencampuradukkan suasana getir, pahit, duka, dengan tawa, lelucon, dan farce.

Dialog kadang-kadang menyajikan kekonyolan. Ini bertujuan untuk memberikan suasana baru dalam dialog serta untuk menghibur supaya rasa kejenuhan dan ketegangan bisa teratasi dengan adanya unsur komedi. adapun masalah lain muncul yakni tentang bau mayat yang dinyatakan oleh Salah Seorang.

(26) SALAH SEORANG : "Waduh, baunya sudah mulai!"

YANG SIMPATI: "Mari kita pindahkan dulu ke sebelah situ. Ayo, kenapa?Ternyata memindah mayat tidak mudah, karena beratnya.Lalu muncullah bau kentut. 
(Wijaya, Ad/1973: 18)

Persoalan data (26) tentang pemindahan jenazah itu menjadi tragedi perdebatan yang panjang dikarenakan berat badan jenazah yang sangat berat. Yang Simpati membuat kekonyolan dengan mengatakan mayat yang mau dipindahkan tiba-tiba mengeluarkan kentut. Ini yang menjadi kekuatan dalam dialog, karena mayat bisa kentut. Unsur humor pun ada ketika mereka belum berhasil memindahkan mayat tapi muncul permasalahan baru yaitu dengan adanya bau kentut.

Teater rakyat Indonesia umumnya tidak mengenal pembagian 'tragedi' dan 'komedi'. Teater mutakhir yang menimba dari teater rakyat juga mencampuradukkan suasana getir, pahit, duka, dengan tawa, lelucon, dan farce. Dialog kadang-kadang menyajikan kekonyolan. Ini bertujuan untuk memberikan suasana baru dalam dialog serta untuk menghibur supaya rasa kejenuhan dan ketegangan bisa teratasi dengan adanya unsur komedi.

Untuk membuktikan dirinya bersih dan jujur mereka ingin berunding dengan kelompok pemakan. Kenyataannya sebelum berunding mereka mengadakan diskusi, dan diskusinya berakhir dengan kekonyolan. Guna membuktikan dirinya jujur, kelompok penguntit rela melepaskan semua pakaian dan meletakkan senjata dan tinggal memakai selembar celana kolor saja.

(27) PENGUNTIT :Ya (sambil membuka segan). Yalah (cepat membuka sehingga tinggal celana kolor saja). Kalian di sana harus percaya saya tidak menyimpan senjata tajam di bawah kolor ini, tetapi kalian harus dibuka juga, demi kebenaran apa boleh buat (siap membuka, tapi tidak berani). Tak usah saja ya?

YANG NGIBUL: Yakin tidak menyembunyikan apa-apa di bawah ya?

YANG NGIBUL: Sssst!!!! Saudara-saudara, sedikit demi sedikit, demi kehormatan kita, buka semuanya cepat! (yang setuju

42 | ISSN: 22477-5150 http://journal.unesa.ac.id/index.php/jpi 
semuanya cepat membuka sehingga rata-rata mereka memakai kolor saja). Jangan malu berterus terang, mari berhadapan dengan mereka dengan modal tubuh, kalau dengan ini toh masih tetap mereka tidak percaya dan curiga, baru kita gebrak! (memperhatikan hasil seruannya dengan cukup puas, lalu mendatangi yang jujur). Begini maksudnya bukan?

(Wijaya, Ed/1976: 15)

Dalam data (27) Rangsangan yang ditimbulkan oleh penguntit membuat kekonyolan dalam adegan ini. Hal ini dibuktikan dengan adanya adegan membuka celana kolor dan bermodal tubuh saja untuk membuktikan sebuah kebenaran.Inilah tragedi dan komedi yang lucu dan jarang ada dalam sebuah kehidupan.

Tragedi dan komedi tidak dapat dilepaskan dari kehidupan manusia. Setiap tindakan yang dilakukan sering mengandung humor. Banyak hal tanpa disadari terkadang membuat kita tertawa dan menangis. Manusia seakan gembira dan tersenyum ketika ada sebuah humor yang merasuk pada otaknya. Orang yang sedih bisa gembira ketika tersenyum, orang sakit bisa sembuh ketika bisa tertawa. Lelucon itu terkadang ada bisa berupa lewat dialog, tulisan, kejadian atau peristiwa. Masuknya unsur humor dan lelucon sebagai bentuk kesempurnaan dalam dialog Suami dan Istri.

(28) ISTRI : Memang! Kalau normal, apa mesti beli marmer!

SUAMI: Kalau tidak dibeli harganya sudah lima kali lipat! Kau menyesal beli barang ini? Bodoh!

ISTRI : Orang normal tidak ada yang mau beli peti mati sebelum mati!

SUAMI: Itu gagasan!

ISTRI : Gagasan edan!

(Wijaya, Dg/1994: 49)

Data (28) tentang penyesalan membeli marmer untuk peti mati merupakan tragedi. Dialog Suami Istri semakin konyol dengan gagasan 
edannya untuk mau membeli peti mati sebelum mati. Inilah letak humornya, yang mana kalau dinalar akal sehat tidak masuk akal.

Berdasarkan analisis tersebut, drama Putu Wijaya mengalami tragedi dan komedi yang ditandai dengan pemindahan jenazah dan bau kentut, adegan membuka celana kolor, mandi dalam keadaan sakit, suara pecah dan teriakan Istri.

Yang paling kuat unsur humornya adalah drama Aduh dan Edan karena dialog yang ada begitu lucu dan menghibur sehingga banyak orang tertawa ketika menikmati adegan-adegan yang diciptakan oleh Putu Wijaya.

\section{SIMPULAN}

Eksistensialisme dalam drama Aduh, Edan, Dag Dig Dug karya Putu Wijaya, adalah (1) kebebasan yang ditandai dengan nama tokoh yang bebas, dialog yang bebas, kebebasan menentukan keputusan, tanpa adanya batasan antar tokoh, (2) kecemasan yang ditandai dengan perasaan tertindih, katakutan, ketidakpercayaan dan curiga, kebingungan pada tokoh, perang batin, (3) kegagalan yang ditandai tidak bisa menjawab pertanyaan, tidak ada bukti dalam berunding, ketidakmampuan mengingat nama, (4) kesia-siaan yang ditandai tokoh yang menunggu, pengulangan peristiwa, kondisi capek, pembuatan makam, dan (5) kematian yang ditandai suasana ironis, proses penguburan dan kecelakaan, pembunuhan tragis.

Absurdisme dalam drama Aduh, Edan, Dag Dig Dug karya Putu Wijaya, adalah (1) bunuh diri filosofis; yang ditandai rasa tidak bias berbuat, tindakan kontradiktif, (2) sifat simbolik; yang ditandai dengan kejadian misterius, waktu, suara, nyanyian, angka abjad, bau, tanggal 44 | ISSN: 22477-5150 http://journal.unesa.ac.id/index.php/jpi 
merah, (3) tragedi dan komedi; yang ditandai pemindahan jenazah dan bau kentut, adegaan membuka celana kolor, mandi dalam keadaan sakit, suara pecah dan teriakan istri.

\section{DAFTAR RUJUKAN}

Abdullah, Imran (Ed.). 1985. Memahami Drama Putu Wijaya: Aduh. Jakarta:Pusat Pengembangan Bahasa Dekdipbud.

Budianta, Melani dkk. 2007. Absurdisme dalam Sastra Indonesia. Jakarta: Pusat Bahasa Departemen Pendidikan Nasional.

Camus, Albert. 1999. Mite Sisifus Pergulatan dengan Absurditas. Jakarta: PT.Gramedia Pustaka Utama.

Damono, Sapardi Djoko, dkk.2007. Absurdisme dalam sastra Indonesia. Jakarta: Pusat Bahasa.

Endraswara, Suwardi. 2011. Metodologi Penelitian Sastra Bandingan. Jakarta: Bukupop.

Endraswara, Suwardi. 2012. Metodologi Penelitian Filsafat Sartra. Yogyakarta: Layar Kata.

Endraswara, Suwardi. 2012. Filsafat Sastra.Yogyakarta: Layar Kata.

Heidegger, Martin. 2003. Heidegger dan Mistik Keseharian (suatu pengantar menuju sein und zeit). Jakarta: Kepustakaan Popular Gramedia.

Jabrohim, dkk. 2000. Metodologi Penelian Sastra. Yogyakarta: Hanindita. Martin, Vincent O.P. 2002. Filsafat Eksistensialisme. Yogyakarta: Pustaka Pelajar.

Purnamasari, Deasy. 2013. Absurditas dan Eksistensialisme dalam novel Siddhartha karya Herman Hesse. Tesis Magister, Unesa. 
Ratna, Nyoman Kutha. 2009. Teori, Metode, dan Teknik Penelitian Sastra. Yogyakarta. Putaka Pelajar.

Sartre, Jean Paul. 2011. Filsafat Eksistensialisme. Yogyakarta: Kanisius.

Sumardjo, Jakob, dan Saini K.M. 1994. Apresiasi Kesusastraan. Jakarta: PT Gramedia Pustaka Utama.

Wellek. Rene dan Austin Warren. 1990. Teori Kesusastraan (Terj. Melani Budianta). Jakarta: Gramedia.

Wijaya, Putu. 1973. Aduh.Jakarta: Pustaka Jaya.

Wijaya, Putu.1976. “Edan” dalam Budaya Jaya X no.106, Maret 1976.

Wijaya, Putu.1994. Dag Dig Dug (Sandiwara Tiga Babak). Jakarta: Balai Pustaka. 